\title{
A study on distribution of chlorophyll-a in the coastal waters of Anzali Port, south Caspian Sea
}

S. Jamshidi ${ }^{1,2}$ and N. Bin Abu Bakar ${ }^{1}$

${ }^{1}$ School of Physics, Universiti Sains Malaysia, 11800 USM, Penang, Malaysia

${ }^{2}$ Department of Physical Oceanography, Iranian National Institute for Oceanography, Tehran, 1411813389, Iran

Received: 23 December 2010 - Accepted: 11 February 2011 - Published: 28 February 2011 Correspondence to: S. Jamshidi (si.jamshidi@gmail.com)

Published by Copernicus Publications on behalf of the European Geosciences Union.

Distribution of chlorophyll-a in the Caspian Sea

S. Jamshidi and

N. Bin Abu Bakar

Title Page

Abstract

Conclusions

Tables

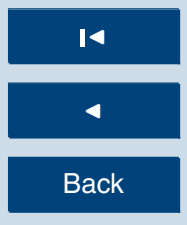

Full Screen / Esc

Printer-friendly Version

Interactive Discussion 


\section{Abstract}

Phytoplankton as chlorophyll-containing organisms is the first step of production in most marine processes and food chains. Nutrient enhancement in the seawater due to the discharge of agricultural, industrial, and urban wastes threatens the Caspian

5 Sea environment. Increasing concentrations of chlorophyll-a in seawater, in reaction to the elevation of nutrient supply can have severely damaging effects on the marine environment of the Caspian. In this research, seasonal variability of the chlorophyll-a concentrations in the western part of the southern coastal waters of the Caspian Sea near Iranian coast was examined using field observations. The data showed that the most chlorophyll-a was found below the sea surface. The thermal stratification in water column and outflow of the Anzali Lagoon affect the chlorophyll-a concentrations in the region. Concentrations of chlorophyll-a were recorded in midsummer in a range of $0.2-3.4 \mathrm{mg} \mathrm{m}^{-3}$.

\section{Introduction}

\subsection{The Caspian Sea}

The Caspian Sea, with surface area of $400000 \mathrm{~km}^{2}$ and length of coastline about $7500 \mathrm{~km}$ (at about $27 \mathrm{~m}$ depth below the ocean level) is the largest enclosed water body in the world. It contains rich hydrocarbon reserves and biological resources (Dumont, 1998; Zonn, 2005a, b; Kosarev and Kostianoy, 2005). The length of the sea from south to north is more than $1030 \mathrm{~km}$, and its width from west to east is in a range of 200-400 km (Zenkovich, 1963; Klig and Myagkov, 1992; Kosarev, 2005). According to the meridional extent of the Caspian Sea, there are several climate zones over the sea. The climate in the southern Caspian Sea is subtropical which is influenced in winter by southern cyclones and a stable and dry weather in summer (Kosarev, 2005). Based on surface monitoring in the Caspian Sea, the northern basin had the largest diversity
OSD

$8,435-451,2011$

Distribution of chlorophyll-a in the Caspian Sea

S. Jamshidi and

N. Bin Abu Bakar

\section{Title Page}

Abstract Introduction

Conclusions

References

Tables

Figures

14

4

Back

Close

Printer-friendly Version

Interactive Discussion 
and productivity relative to the middle and southern parts of the sea (Kasymov and Rogers, 1996). Due to the isolation of the Caspian Sea from the open seas, its natural regime, hydrological structure and circulation are affected by external factors such as discharge of rivers and atmospheric processes (Tuzhilkin and Kosarev, 2005). About 5130 rivers with various outflow volumes enter the sea. The main sources of freshwater inputs to the Caspian Sea are the Volga (with a total volume of about $80-85 \%$ of inflow), Ural, Emba, Terek Rivers in the north (Rodionov, 1994; Mamedov, 1997). In the south, the total volume inflow of the Iranian rivers to the sea is about $4-5 \%$; the Sepidrood River (originating from the Elburs Mountains) is the largest (Kosarev, 10 2005; CEP, 2002). Surface water temperature in this part was reported to be about $10^{\circ} \mathrm{C}$ in winter and $27-28^{\circ} \mathrm{C}$ in summer (Dumont, 1998). Based on the International Atomic Energy Agency (IAEA) measurements near the Iranian coasts in September 1995 , surface water temperature was about $27.5^{\circ} \mathrm{C}$ with salinity of 12.24 PSU (IAEA, 1996).

\subsection{Chlorophyll-a in the Caspian Sea}

Chlorophyll-containing organisms are the first step of production in the most food chains, and the health and abundance of these primary producers affect the integrity of the other trophic levels in the Caspian Sea. The northern region (shallow water) and deep-water zone of the Caspian Sea in the middle and southern parts are dif-

ferent in ecological and hydrological characteristics. Chlorophyll-a concentrations in various parts of the Caspian Sea are affected by some important factors such as air and seawater temperatures, wind stress anomalies over various areas of the sea, and discharge of the Volga and Ural Rivers (Nezlin, 2005). In the deep-water zone of the middle and southern Caspian Sea, thermal structure and stratification of the water column regulate the concentrations of chlorophyll-a. In this region, the seasonal sharp
thermocline in summer acts as a barrier resulting in natural nutrient limitation for phy-
toplankton growth. In the northern part of the Caspian Sea, interannual and seasonal

\section{OSD}

$8,435-451,2011$

\section{Distribution of chlorophyll-a in the Caspian Sea \\ S. Jamshidi and \\ N. Bin Abu Bakar}

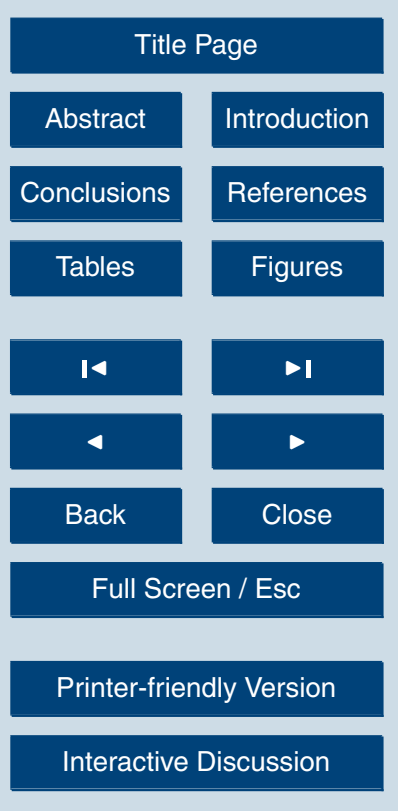


variability of phytoplankton biomass is under the influence of freshwater discharges of the Volga River. The seasonal pattern of chlorophyll concentration (based on Sea WiFS observations 1997-2004) shows that the maximum values in the southern Caspian Sea occurred at the surface layer in August. Generally, chlorophyll concentration in 5 the northern Caspian Sea is higher than its concentrations in the southern and middle deep parts of the Caspian Sea (Nezlin, 2005).

The Caspian environment is under high stress, due to the extensive exploitation and discharge of large magnitudes of human waste such as discharge of domestic sewage waters, industrial and agricultural wastewater that contain nutrients, pesticides and de10 tergents that threatens the Caspian ecosystems (Kosarev and Kostianoy, 2005; Zonn, 2005b; Korshenko and Gul, 2005). For example, a large scale Anomalous Algal Bloom (AAB) was observed for the first time in the southern basin of the Caspian Sea during August-September 2005. The algal bloom was a consequence of the highly increased concentration of phytoplankton following increased nutrient input to the Caspian sea5 water (CEP, 2006).

In addition, maximum levels of the chlorophyll-a concentration (i.e. phytoplankton biomass) were observed in the middle and southern parts of the Caspian Sea in summer 2001 (Kideys et al., 2008; Nezlin, 2005). This phenomenon was not related to the changes in physical conditions such as water temperature or wind stress. Some authors believe that maximum levels of phytoplankton (maximum values of chlorophyll-a concentrations) was due to the invasion of Mnemiopsis Leidyi, which was observed in the middle and southern basin of the sea (Kideys et al., 2008; Kideys and Moghim, 2003; Nezlin, 2005).

Very low and high levels of concentrations of chlorophyll-a can be harmful to marine

biota. Chlorophyll concentration is one of the key indices in the study of the health status of any natural marine ecosystem. Therefore, the investigation on variations of chlorophyll-a is very important to the study of water quality and marine pollution in the Caspian Sea. Variability of chlorophyll-a concentrations determines the ecological conditions of marine systems such as the changes in the physical and chemical
OSD

$8,435-451,2011$

\section{Distribution of chlorophyll-a in the Caspian Sea}

S. Jamshidi and

N. Bin Abu Bakar

Title Page

Abstract Introduction

Conclusions

Tables

References

Figures

14

$\rightarrow 1$

4

Back

Close

Printer-friendly Version

Interactive Discussion 
characteristics of the environment. One of the fundamental interests of oceanographers is the investigation of ecological characteristics of seawater.

In previous studies, the monitoring of the chlorophyll-a concentrations in the Southern Caspian Sea is organized based on satellite data sets (e.g. Nezlin, 2005; Kideys 5 et al., 2008). The vertical structure of chlorophyll-a concentrations and its variations in deeper layers of the southern Caspian seawater are not well known (Kideys et al., 2008; Nezlin, 2005) and needs more investigation.

The objective of the study is an investigation on the concentrations and structure of chlorophyll-a in the southern coastal waters of the Caspian Sea. For this purpose, 10 the seasonal distributions of chlorophyll-a near to Anzali Port in north of Iran were evaluated using in situ measurements.

\section{Material and methods}

The analysis conducted in this work was based on experimental observations in the southern part of the Caspian Sea. Data collection were performed in spring (April), 15 summer (August) and autumn (November) in the southern coastal waters of the Caspian Sea by using a small research vessel. The study area was located in the west part of the southern coastal waters of the Caspian Sea near the Iranian boundary between latitudes of $37^{\circ} 29^{\prime} \mathrm{N}$ and $37^{\circ} 39^{\prime} \mathrm{N}$ and between longitudes of $49^{\circ} 25^{\prime} \mathrm{E}$ and $49^{\circ} 45^{\prime} \mathrm{E}$. The sampling stations were located in a rectangular area of coastal wa20 ters with the length of $25 \mathrm{~km}$ and width of $15 \mathrm{~km}$ adjacent to Anzali Port and Lagoon. Figure 1 indicates study area and positions of field survey stations. Mean temperature in Anzali Lagoon is reported as about $16^{\circ} \mathrm{C}$, which varies from $4.5^{\circ} \mathrm{C}$ in winter (February) to $27.5^{\circ} \mathrm{C}$ in midsummer (August) (Asadullayeva and Alekperov, 2007). In the investigated area, depth from the west to the east increases and reaches to about $500 \mathrm{~m}$. In the eastern part, continental shelf has a width of $8 \mathrm{~km}$ and a maximum depth about $50 \mathrm{~m}$. Here, the depth from the coast increases gently to about $50 \mathrm{~m}$ near the shelf break and after that reaches to $200 \mathrm{~m}$ depth at about $12 \mathrm{~km}$ (Zaker, 2007). Field

\section{OSD}

$8,435-451,2011$

Distribution of chlorophyll-a in the Caspian Sea

S. Jamshidi and

N. Bin Abu Bakar

Title Page

Abstract Introduction

Conclusions

Tables

References

Figures

14

4

Back

Close

Full Screen / Esc

Printer-friendly Version

Interactive Discussion 
observations in the study area were carried out at 23 stations along four survey lines perpendicular to the coastline and two transects parallel to the coast in year 2008. Distance between the stations reached to an average of $2 \mathrm{~km}$ along transects. A portable Ocean Seven 316 CTD probe developed by IDRONAUT was applied. Probe was set 5 in Timed Data Acquisition mode for profiling. The profiler was used in free-fall mode at one metre per second recording at one-second time intervals.

\section{Results}

Chlorophyll-a concentrations can act as an indicator of phytoplankton abundance and biomass in the coastal waters. It is natural for levels of chlorophyll-a to fluctuate over 10 the different seasons. In this paper, variations of chlorophyll-a in upper layers of Iranian coastal waters of the Caspian Sea are presented. Seasonal variability in the vertical distribution of chlorophyll-a along transects $A B$ and $C D$ perpendicular to the coastline and near to mouth of the Anzali Lagoon are presented in Fig. 2. Here at the time of measurements in early spring (April), the concentrations of chlorophyll-a increased 15 with depth. Concentrations at the sea surface mainly varied between $1.3-1.4 \mathrm{mg} \mathrm{m}^{-3}$ along transect $A B$ while in transect $C D$ the values were in range of $1.1-1.4 \mathrm{mg} \mathrm{m}^{-3}$. Maximum value of chlorophyll-a was recorded around $2.1 \mathrm{mg} \mathrm{m}^{-3}$ at depth of $20 \mathrm{~m}$ in both transects (Fig. $2 a$ and d). Vertical gradient of concentrations in transects $A B$ and $C D$ in midsummer (August) was more than early spring (April). According to the 20 measured data in summer, maximum value of chlorophyll-a in transect $A B$ was around $3.4 \mathrm{mg} \mathrm{m}^{-3}$ at $5 \mathrm{~m}$ depth while minimal was $0.4 \mathrm{mg} \mathrm{m}^{-3}$ between $15-20 \mathrm{~m}$ (Fig. 2b). In transect $C D$, maximal and minimal chlorophyll-a were $2.4 \mathrm{mg} \mathrm{m}^{-3}$ around $5 \mathrm{~m}$ depth and $0.2 \mathrm{mg} \mathrm{m}^{-3}$ below $25 \mathrm{~m}$ depth, respectively (Fig. 2e). In August horizontal gradient of chlorophyll-a in $2 \mathrm{~m}$ upper layer at the sea surface was very slight and contour line of $250.6 \mathrm{mg} \mathrm{m}^{-3}$ concentration was horizontal (Fig. 2b). In November, concentrations near the sea surface in transect $A B$ were recorded between $2-2.1 \mathrm{mg} \mathrm{m}^{-3}$. As it can be seen in Fig. 2c, the concentrations enhanced to $2.4 \mathrm{mg} \mathrm{m}^{-3}$ from the sea surface to depth

\section{OSD}

8, 435-451, 2011

\section{Distribution of chlorophyll-a in the Caspian Sea}

S. Jamshidi and N. Bin Abu Bakar

Title Page

\section{Full Screen / Esc}

Printer-friendly Version

Interactive Discussion 
of $5 \mathrm{~m}$. In deeper layers and below $20 \mathrm{~m}$ depth, chlorophyll-a concentrations reached $1.7 \mathrm{mg} \mathrm{m}^{-3}$ (Fig. 2c). Along transect CD, this trend can be seen in the distance of $8 \mathrm{~km}$ from the beginning of the section (Fig. 2e). At the end part of this section in offshore stations, concentrations were $1.6 \mathrm{mg} \mathrm{m}^{-3}$ at the depth $45 \mathrm{~m}$. The seasonal distributions

5 of chlorophyll-a along both of transects $A B$ and CD showed that concentrations at the time of measurements in autumn (November) and summer (August) were more than concentrations in spring (April). Below $25 \mathrm{~m}$ depth in transect $C D$, values in summertime observations were very low $\left(0.2 \mathrm{mg} \mathrm{m}^{-3}\right)$ and smaller than in spring and autumn seasons. Seasonal features along transects $A B$ and $C D$ determine how much biologi10 cal production occurs in area in front of Lagoon mouth. In surface layer of transect CD in April and November, concentrations increased from the coast towards the offshore stations. Over the continental shelf (along transect $A B$ ), compression of contour lines of concentrations in spring (April) and autumn (November) seasons were less than in midsummer (August). As shown in Fig. 2c, below $5 \mathrm{~m}$ depth, values of chlorophyll-a 15 concentrations decreased with depth. Seasonal distributions of chlorophyll-a along transects EF and $\mathrm{GH}$ are displayed in Fig. 3. In April, concentrations ranged between $1-1.4 \mathrm{mg} \mathrm{m}^{-3}$ in the surface layer and increased to $2.2 \mathrm{mg} \mathrm{m}^{-3}$ over the shelf break (Fig. 2d). At this time, values of chlorophyll-a concentrations below $35 \mathrm{~m}$ depth along transect $\mathrm{GH}$ were less than transect EF. Below $35 \mathrm{~m}$ depth in transect $\mathrm{GH}$, levels 20 of chlorophyll-a rapidly fall down to a minimum value of $0.4 \mathrm{mg} \mathrm{m}^{-3}$. In midsummer (August), the maximum level of concentrations $\left(2.8 \mathrm{mg} \mathrm{m}^{-3}\right)$ was recorded between $10-15 \mathrm{~m}$ depths. Contour lines at the subsurface layer indicated higher concentrations in comparison to the sea surface in August. In summertime, vertical difference of chlorophyll-a concentrations reached around $1.6 \mathrm{mg} \mathrm{m}^{-3}$. In November, concentrations of chlorophyll-a in transect EF grew from the beginning of transect until the shelf break (Fig. 3c). The highest value recorded was about $2.6 \mathrm{mg} \mathrm{m}^{-3}$ between depths of $5-10 \mathrm{~m}$ (Fig. 3c). In offshore stations and below depth of $35 \mathrm{~m}$, contour line of $1.8-1.6 \mathrm{mg} \mathrm{m}^{-3}$ can be clearly seen (Fig. 3c). In transect GH, horizontal gradient of concentrations was considerable at the surface layer (Fig. 3f). In offshore stations and far from the

\section{OSD}

$8,435-451,2011$

\section{Distribution of chlorophyll-a in the Caspian Sea}

S. Jamshidi and

N. Bin Abu Bakar

Title Page

Abstract Introduction

Conclusions

Tables

References

Figures

14

4

Back

Close
- I

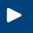

Printer-friendly Version

Interactive Discussion

Full Screen / Esc 
continental shelf along the transect $\mathrm{GH}$, values decreased from $5 \mathrm{~m}$ depth to $50 \mathrm{~m}$ depth (Fig. 3f).

The structures of chlorophyll-a levels along two transects ( $\mathrm{AG}$ and $\mathrm{BH}$ ) parallel to the coastline are shown in Fig. 4. In transect AG in April, the range of chlorophyll-a 5 was between $1 \mathrm{mg} \mathrm{m}^{-3}$ at the surface and $1.8 \mathrm{mg} \mathrm{m}^{-3}$ below $10 \mathrm{~m}$ depth (Fig. $4 \mathrm{a}$ ). In midsummer, gradient of concentrations at the beginning of transect near the mouth of the Lagoon was substantial (Fig. 4b). The vertical gradient at the end part of transect decreased and values of chlorophyll-a changed from $1.6 \mathrm{mg} \mathrm{m}^{-3}$ to $2 \mathrm{mg} \mathrm{m}^{-3}$ (Fig. 4b). During the measurements in November, concentrations varied between 2.2 10 and $1 \mathrm{mg} \mathrm{m}^{-3}$ (Fig. 4c). Distribution of chlorophyll-a concentration along transect $\mathrm{BH}$ indicated a maximum of $1.8 \mathrm{mg} \mathrm{m}^{-3}$ and a minimum of $0.4 \mathrm{mg} \mathrm{m}^{-3}$ in April (Fig. $4 \mathrm{~d}$ ). At a distance of $10 \mathrm{~km}$ from the beginning of transect, entrance of the Lagoon water with lower values is seen. Based on collected data in midsummer (August), concentrations in $20 \mathrm{~m}$ upper layer were more than below (Fig. 4e). At this time chlorophyll-a 15 values of $2.8 \mathrm{mg} \mathrm{m}^{-3}$ at level of $10 \mathrm{~m}$ were observed. In November, the concentrations of chlorophyll-a ranged between $1.6-2.2 \mathrm{mg} \mathrm{m}^{-3}$ at the surface layer which increased to $2.6 \mathrm{mg} \mathrm{m}^{-3}$ below $15 \mathrm{~m}$ depth (Fig. $4 \mathrm{f}$ ).

\section{Discussion}

The distributions of chlorophyll-a concentrations in the southern coastal waters of the 20 Caspian Sea in year 2008 were presented and discussed. For this purpose the results of measured chlorophyll-a data in different seasons were analyzed.

Physical structure of water column and variations of seawater properties (such as temperature) at the time of observations showed a strong thermal stratification in period of mid-summer to mid-autumn. The vertical structure of temperature in the study area is characterized by a significant seasonal thermocline between $20-50 \mathrm{~m}$ depths in summer. The destruction of the seasonal thermocline occurred with the general cooling of the sea surface water and deepening of the mixed layer during late autumn

\section{OSD}

8, 435-451, 2011

\section{Distribution of} chlorophyll-a in the Caspian Sea

S. Jamshidi and

N. Bin Abu Bakar

\section{Title Page}

\section{Full Screen / Esc}

Printer-friendly Version

Interactive Discussion 
and early winter. Based on our measurements, in March, water temperature at the sea surface varied in a range of $9-10^{\circ} \mathrm{C}$ which gradually decreased to $8^{\circ} \mathrm{C}$ at $100 \mathrm{~m}$ depth. In that time salinity values were between 12.2 psu at the surface and 12.3 psu in $100 \mathrm{~m}$ depth in the offshore area far from the mouth of lagoon. In April, temperature was $518-19^{\circ} \mathrm{C}$ at the surface decreasing to $9-10^{\circ} \mathrm{C}$ at $50 \mathrm{~m}$ depth. In midsummer (August), surface water temperature indicated values around $27^{\circ} \mathrm{C}$ with a decrease to $10^{\circ} \mathrm{C}$ below thermocline at $50 \mathrm{~m}$ level. The variations of salinity were from $12.1 \mathrm{psu}$ to $12.3 \mathrm{in}$ upper $50 \mathrm{~m}$ layer. Surface mixed layer in autumn season (November) had a thickness of $35 \mathrm{~m}$ with temperature of $19-20^{\circ} \mathrm{C}$. In the time of measurement in autumn, the ther10 mocline was located between $35-45 \mathrm{~m}$ depths and temperature at the lower level of thermocline was about $10^{\circ} \mathrm{C}$. Observed data for salinity showed a value of $12.4 \mathrm{psu}$ in this area, which decreased to 12.3 at $100 \mathrm{~m}$ depth (Jamshidi and Bin Abu Bakar, 2011).

In the study area, chlorophyll-a concentrations changed with the aspects that affect phytoplankton growth. Some of those factors were amount of sunlight, nutrient con15 centrations near the coastline and amount of mixing. The chlorophyll-a concentrations were larger in midsummer than other times because the sea surface layers in the region receive more sunlight in summer. In autumn with seasonal changes, destruction of seasonal thermocline and pycnocline starts and nutrients flux into the surface layers. This process can stimulate phytoplankton growth and enhance the concentration of chlorophyll-a. On the other hand, due to the location of the study area near the mouth of Anzali Lagoon, the chlorophyll-a concentrations in the area was under the influence of the lagoon outflow.

In spring, vertical gradient of chlorophyll-a especially over the continental shelf was less than that in summer. In comparison, the maximum values of chlorophyll-a were observed in midsummer. In August, levels of the chlorophyll-a measured near the coastline (at the onshore stations) in the western part of the study region (near mouth of the lagoon) were more than in the eastern area. In total, the concentrations of chlorophyll-a in summer and autumn were larger than recorded values in early spring. The distribution of chlorophyll-a indicated gentle decrease with depth in the area. The
OSD

8, 435-451, 2011

Distribution of chlorophyll-a in the Caspian Sea

S. Jamshidi and

N. Bin Abu Bakar

Title Page

Abstract Introduction

Conclusions

Tables

References

Figures

14

$\rightarrow 1$

4

Back

Close

Full Screen / Esc

Printer-friendly Version

Interactive Discussion 
largest chlorophyll-a concentrations were found near the sea surface, because there is less light at depth. In other words, the highest values of the chlorophyll-a concentrations were often located just below the surface between 5-20 $\mathrm{m}$ depths.

Based on measurements in the coastal waters of Rudsar (Fig. 1) in summer 2008, 5 the amounts of the chlorophyll-a concentrations varied from 3.8 to $0.1 \mathrm{mg} \mathrm{m}^{-3}$ with the maximal levels at $15 \mathrm{~m}$ depth. In addition, chlorophyll-a concentration sharply decreased with depth and reached around $0.5 \mathrm{mg} \mathrm{m}^{-3}$ and $0.1 \mathrm{mg} \mathrm{m}^{-3}$ at $60 \mathrm{~m}$ and below $80 \mathrm{~m}$ depths, respectively (Jamshidi et al., 2010). Therefore, it is found that the largest concentrations of chlorophyll-a in the study area were limited to the upper layers in10 cluding the surface mixed layer and thermocline (around $50 \mathrm{~m}$ surface layers). The seasonal variations of the chlorophyll-a in the region were described by one obvious maximum in midsummer. Nezlin (2005) reported similar phenomenon in the South Caspian Sea.

Investigation on vertical, horizontal and seasonal structures of the chlorophyll-a 15 found that the changes in chlorophyll-a concentrations far from the mouth of the Anzali Lagoon were slight. While near to the mouth of the lagoon, chlorophyll-a concentrations showed a greater range. In offshore stations (deepwater zone), concentrations of chlorophyll-a and process of phytoplankton growth were mainly under effect of thermal stratification of the water column. As it can be seen in Figs. 3 and 4, the most changes of the concentrations outside the shelf were in surface mixed layer and thermocline. In the southern coastal waters of the Caspian Sea, pycnocline was established in position of thermocline layer in warm seasons (Zaker et al., 2007). The formed pycnocline acts as a natural boundary separating the surface warm and well-illuminated layer from the near bottom layer, which is rich in nutrients.

Southern lagoons and coastal regions of the Caspian Sea have been steadily polluted with anthropogenic sources (fertilizer and pesticides used in agriculture and increased nutrient load of river flows due to deforestation of woodland) since the early 1980s. Thus, simultaneous rises in nutrient contributed to increases in chlorophyll-a values (Kideys et al., 2008; Kideys and Moghim, 2003; Kopelevich et al., 2008). Due
OSD

$8,435-451,2011$

\section{Distribution of chlorophyll-a in the Caspian Sea}

S. Jamshidi and

N. Bin Abu Bakar

Title Page

Abstract

Introduction

Conclusions

Tables

References

Figures

14

4

Back

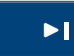

$>1$

$\triangleright$

Close

Printer-friendly Version

Interactive Discussion

Full Screen / Esc 
to the location of the investigated region near the mouth of the Anzali Lagoon, the chlorophyll-a concentrations in the area were high, especially in midsummer. Because of the entrance of pollutant, the environment of the Caspian is under pressure. According to the discharge of local rivers and lagoons in the coastal waters, seawater in 5 the near mouth areas has different conditions from deep water zone as shown by the enhanced chlorophyll-a concentrations. The marine environment of the Caspian Sea needs serious measures to prevent the entrance of the degradable wastes, nutrients and industrial pollutants.

\section{Conclusions}

10 Presented data in this manuscript provide a preliminary knowledge on the distributions of chlorophyll-a in the coastal waters of Anzali Port in the southern Caspian Sea. The results showed that the maximum concentrations of chlorophyll-a were observed around $5 \mathrm{~m}$ depth in summer. Below the thermocline, values of chlorophyll-a rapidly decreased and its concentrations were slightly near the bottom.

15 Higher chlorophyll-a concentrations were recorded during summertime (August) measurements when the water temperature and light levels in the region were higher. The average of the concentrations of chlorophyll-a is an important indicator for the state of the marine environment of the region in the southern Caspian Sea. The structure of the variations of chlorophyll-a in the coastal area and near mouth of estuaries, rivers and lagoons was different in comparison to offshore area. The chlorophyll-a concentrations in the western part of the study area and near mouth area were higher than in the eastern region.

Acknowledgements. The Iranian National Institute for Oceanography (INIO) supported this work (Project No.386-D-02-08, 1386/11/10). We would like to thank all the colleagues at INIO
OSD

8, 435-451, 2011

Distribution of chlorophyll-a in the Caspian Sea

S. Jamshidi and

N. Bin Abu Bakar

Title Page

Abstract Introduction

Conclusions

References

Tables Figures

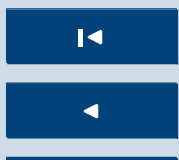

$>1$

Back

Close

Printer-friendly Version

Interactive Discussion 


\section{References}

Asadullayeva, E. and Alekperov, I.: Free-living ciliates of the Anzali Wetland of the Caspian Sea, Turkish Journal Zoology, 31, 143-149, 2007.

CEP: Transboundary Diagnostic Analysis for the Caspian Sea; Baku, Azerbaijan, pp. 36, 2002.

5 CEP: Identification of the extent and causes of cyan bacterial bloom in September-October 2005 and development of the capacity for observation and prediction of HAB in the Southern Caspian Sea using Remote Sensing Technique, MHI, Ukraine, 2006.

Dumont, H. J.: The Caspian Lake: History, Biota, Structure, and Function, Limnol. Oceanogr., 43, 44-52, 1998.

IAEA: Research/Training on the Caspian Sea, Data Report 1995, Vienna: International Atomic Energy Agency, pp. 95, 1996.

Jamshidi, S., Abu Bakar, N. B., and Yousefi, M.: Concentration of chlorophyll-a in the coastal waters of Rudsar, Research Journal Environmental Sciences, 10, 132-138, 2010.

Jamshidi, S. and Abu Bakar, N. B.: Seasonal variations in temperature, salinity and density in the southern coastal waters of the Caspian Sea, Oceanology, in press, 2011.

Kasymov, A. and Rogers, L.: Ecological description of the Southern Caspian Sea in the oil-field region of Guneshly, Political and Ecological Studies, 22, 83-93, 1996.

Kideys, A. E. and Moghim, M.: Distribution of the alien ctenophore Mnemiopsis leidyi in the Caspian Sea in August 2001, Mar. Biol., 142, 163-171, 2003.

Kideys, A. E., Roohi, A., Eker-Develi, E., Melin, F., and Beare, D.: Increased chlorophyll levels in the Southern Caspian Sea following an invasion of jellyfish, Research Letters in Ecology, 4 pages, Hindawi Publishing Corporation, 2008.

Klig, R. K. and Myagkov, M. S.: Change in the Water Regime of the Caspian Sea, GeoJournal, 27, 299-307, 1992.

25 Kopelevich, O. V., Burenkov, V. I., and Sheberstov, S. V.: Biodiversity. Case studies of optical remote sensing in the Barents Sea, Black Sea and Caspian Sea, in: Remote Sensing of the European Seas, part 2, edited by: Barale, V. and Grade, M., 53-66, Springer, 2008.

Korshenko, A. N. and Gul, A. G.: Pollution of the Caspian Sea, in: The Caspian Sea Environment, edited by: Kostianoy, A. G. and Kosarev, A. N., 109-142, Germany: Springer, 2005.

30 Kosarev, A. N.: Physico-Geographical Conditions of the Caspian Sea, in: The Caspian Sea Environment, edited by: Kostianoy, A. G. and Kosarev, A. N., 5-31, Springer, Germany, 2005.
OSD

$8,435-451,2011$

Distribution of chlorophyll-a in the Caspian Sea

S. Jamshidi and

N. Bin Abu Bakar

Title Page

Abstract

Introduction

Conclusions

References

Tables

Figures

14

4

Back

Close

Printer-friendly Version

Interactive Discussion 
Kosarev, A. N. and Kostianoy, A. G.: Introduction, in: The Caspian Sea Environment, edited by: Kostianoy, A. G. and Kosarev, A. N., 1-3, Springer, Germany, 2005.

Mamedov, A. V.: The late pleistocene-holocene history of the Caspian Sea, Quat. Int., 41/42, 161-166, 1997.

5 Nezlin, N. P.: Pattern of seasonal and interannual variability of remote sensed chlorophyll, in: The Caspian Sea Environment, edited by: Kostianoy, A. G. and Kosarev, A. N., 143-157, Springer, Germany, 2005.

Rodionov, S. N.: Global and regional climate interaction: the Caspian Sea experience, Water Science and Technology Library, Kluwer Academic Publisher, Dordrecht, pp. 241, 1994.

10 Tuzhilkin, V. S. and Kosarev, A. N.: Thermohaline structure and general circulation of the Caspian Sea waters, in: The Caspian Sea environment, edited by: Kostianoy, A. G. and Kosarev, A. N., 33-58, Springer, Germany, 2005.

Zaker, N. H.: Characteristics and seasonal variations of dissolved oxygen, Int. J. Environ. Res., 1, 296-301, 2007.

Zaker, N. H., Ghaffari, P., and Jamshidi, S.: Physical study of the southern coastal waters of the Caspian Sea, off Babolsar, Mazandaran in Iran, J. Coastal Research SI, 50, 564-569, 2007.

Zenkovich, L. A.: Biology of the Seas of the USSR; Nauka, Moscow, 1963 (In Russian).

Zonn, I. S.: Environmental issues of the Caspian, in: The Caspian Sea Environment, edited by: Kostianoy, A. G. and Kosarev, A. N., 223-242, Springer, Germany, 2005a.

Zonn, I. S.: Economic and international legal dimensions, in: The Caspian Sea Environment, edited by: Kostianoy, A. G. and Kosarev, A. N., 243-256, Springer, Germany, 2005b.

\section{OSD}

8, 435-451, 2011

Distribution of chlorophyll-a in the Caspian Sea

S. Jamshidi and

N. Bin Abu Bakar

Title Page

Abstract

Introduction

Conclusions

References

Tables

Figures

14

4

Back

Close

Full Screen / Esc

Printer-friendly Version

Interactive Discussion 


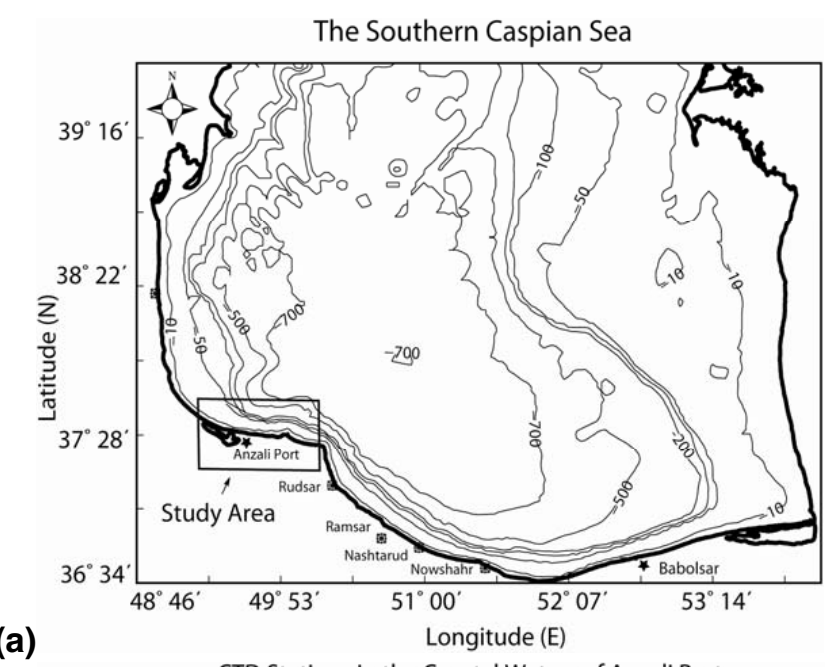

\section{OSD}

8, 435-451, 2011

\section{Distribution of chlorophyll-a in the Caspian Sea}

S. Jamshidi and N. Bin Abu Bakar

Title Page

Abstract Introduction

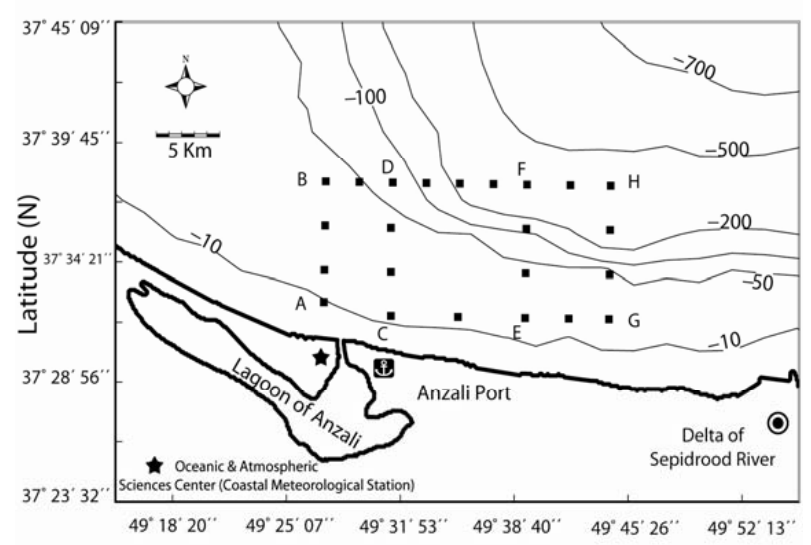

Conclusions

References

\section{Tables}

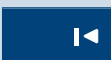

4

Back

\section{Figures}

4

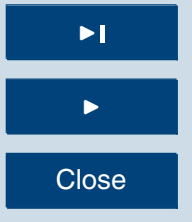

Full Screen / Esc

Printer-friendly Version

Interactive Discussion

Fig. 1. (a) Study area in the southern Caspian Sea and (b) positions of sampling stations. 

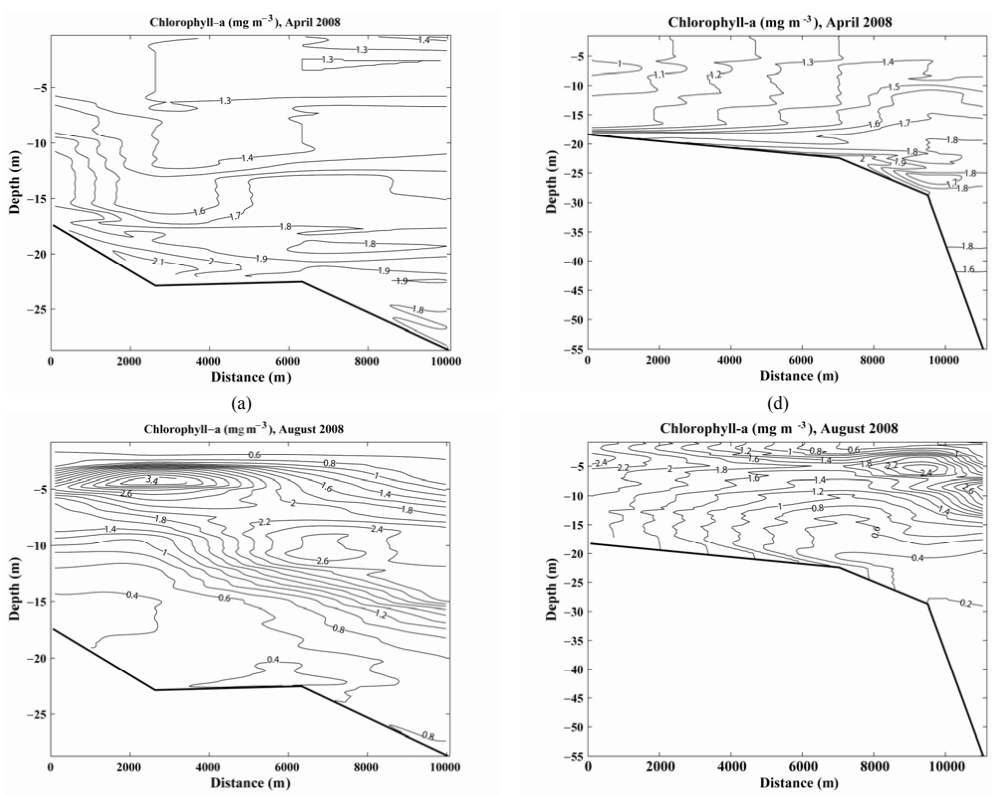

(b)

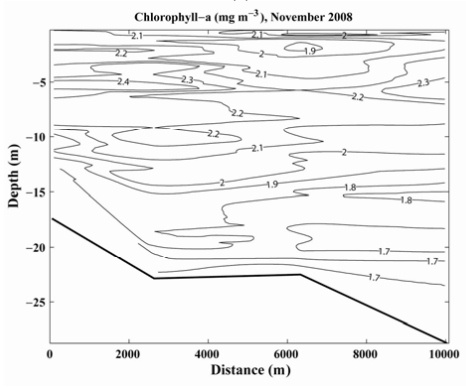

(c)

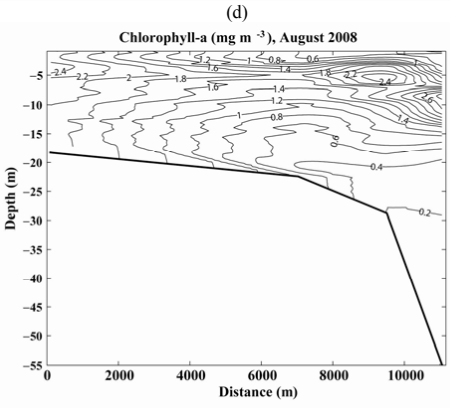

(e)

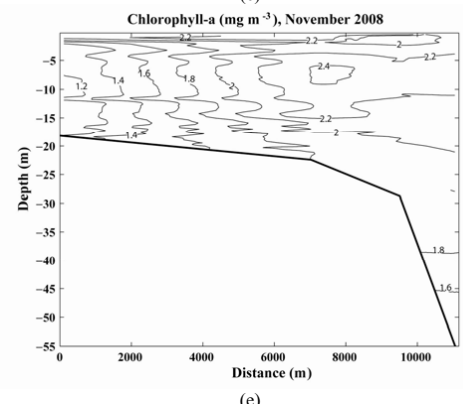

(e)

Fig. 2. Seasonal variations of the chlorophyll-a along transects $A B$ (left panel) and $C D$ (right panel).

\section{$8,435-451,2011$}

\section{Distribution of chlorophyll-a in the Caspian Sea}

S. Jamshidi and N. Bin Abu Bakar

Title Page

Abstract Introduction

Conclusions

References

Tables

Figures

14

4

Back

Close

Full Screen / Esc

Printer-friendly Version

Interactive Discussion 


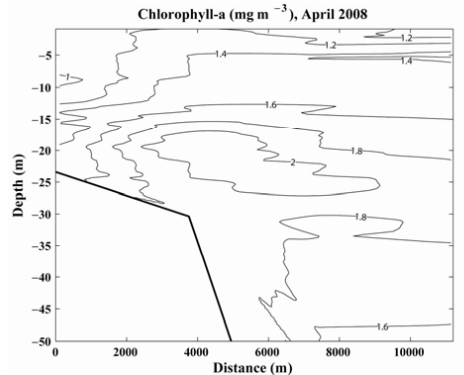

(a)

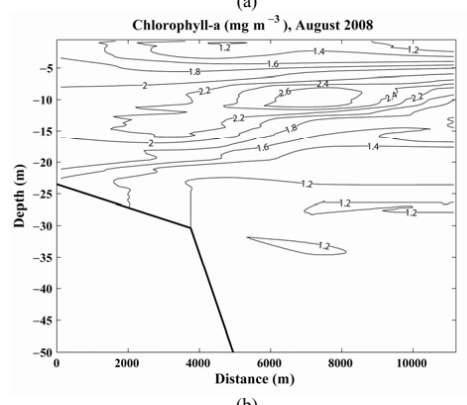

(b)

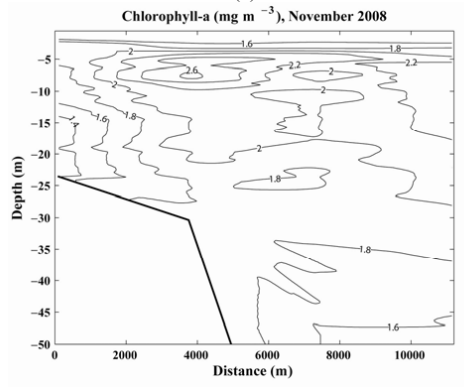

(c)
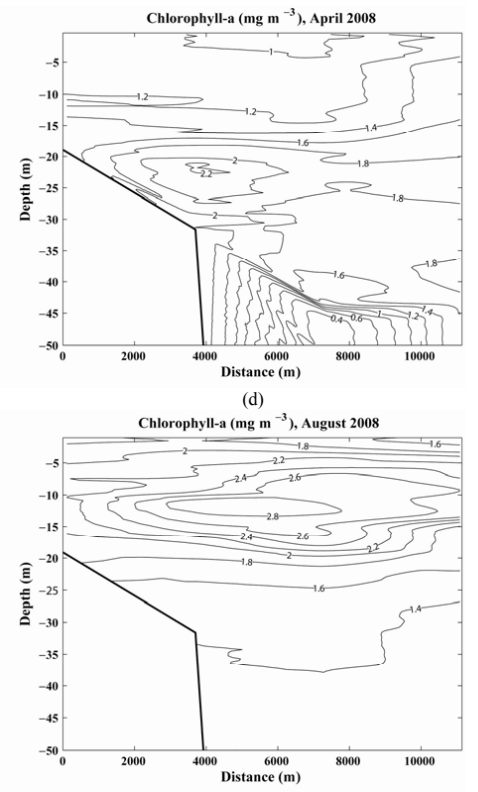

(e)

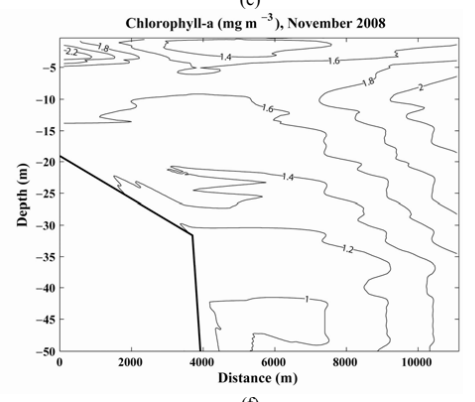

(f)

Fig. 3. Seasonal variations of the chlorophyll-a along transects EF (left panel) and GH (right panel).

\section{$8,435-451,2011$}

\section{Distribution of chlorophyll-a in the Caspian Sea}

S. Jamshidi and N. Bin Abu Bakar

Title Page

Abstract Introduction

Conclusions

References

Tables

Figures

14

4

Back

$\Delta$
-1
Close

Full Screen / Esc

Printer-friendly Version

Interactive Discussion 


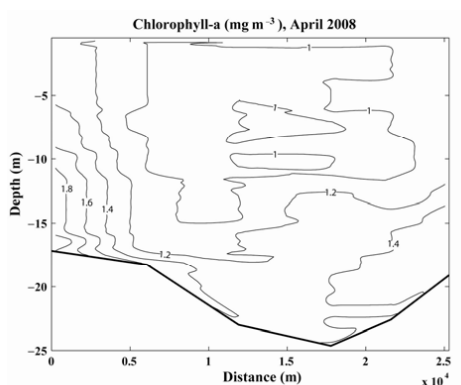

(a)
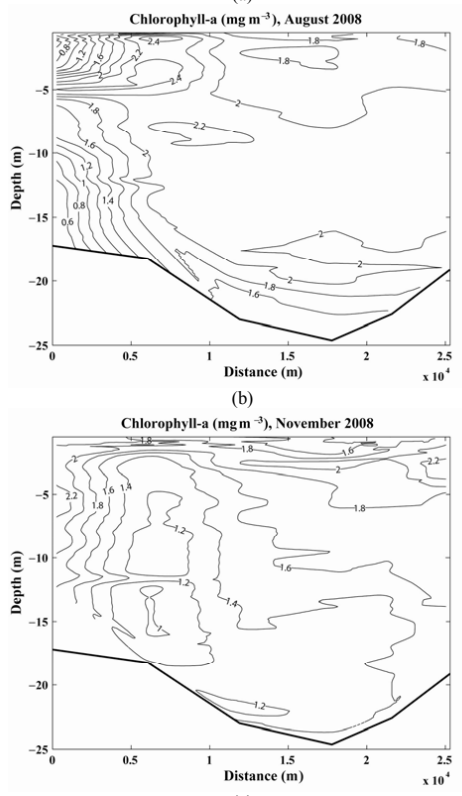

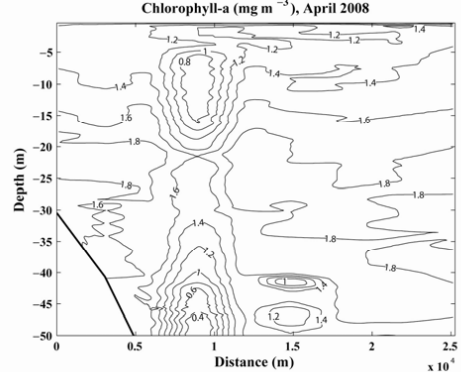

(d)
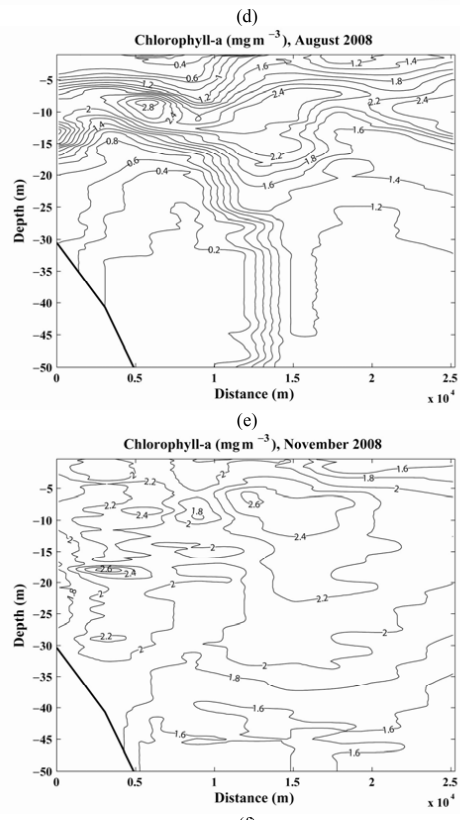

OSD

8, 435-451, 2011

Distribution of chlorophyll-a in the Caspian Sea

S. Jamshidi and N. Bin Abu Bakar

Title Page

Abstract

Introduction

Conclusions

References

Tables

Figures

14

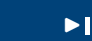

4

Back

Close

Full Screen / Esc

Printer-friendly Version

Interactive Discussion panel). 